\title{
Pelatihan Promosi Kesehatan pada Tenaga Kesehatan di Jawa Barat
}

\author{
Yustikasari ${ }^{1}$, Renata Anissa ${ }^{2}$, Retasari Dewi ${ }^{3}$ \\ Universitas Padjadjaran, Bandung, Jawa Barat, Indonesia
}

\begin{abstract}
ABSTRAK
Promosi kesehatan adalah kegiatan yang wajib dilaksanakan di tenaga kesehatan dan instansi kesehatan. Akan tetapi dimasa pandemi, banyak kegiatan promkes yang tidak bisa dilaksanakan. Disisi lain banyak berita hoaks yang beredar di media sosial, karena masyarakat lebih memilih media sosial dan televisi sebagai sumber informasi. Untuk itu diperlukan upaya promosi kesehatan yang dilakukan melalui media sosial. Tujuan dari kegiatan pelatihan ini adalah meningkatkan pemahaman promosi kesehatan bagi tenaga kesehatan, meningkatkan pemahaman promosi kesehatan serta hubungannya dengan citra rumah sakit, dan meningkatkan kemampuan pengelolaan pesan di media sosial untuk tujuan promosi kesehatan. Kegiatan ini merupakan kerjasama tim Pengabdian Pada Masyarakat Dosen (PPMD) dan tim Kuliah Kerja Nyata Mahasiswa (KKNM) Universitas Padjadjaran. Pelatihan ini menghadirkan dr. Imran Agus Nurali, Sp.KO., dr. Nurhidayat, M.Kes., DPDK, dan Muhammad Afif sebagai pembicara. Hasil dari kegiatan pelatihan ini, dapat disimpulkan bahwa pemahaman mengenai pesan promosi kesehatan antara promotor kesehatan dan audience sasaran masih belum sejalan; Keberadaan promotor kesehatan di instansi kesehatan penting, karena dapat menjadi strategi peningkatan citra positif instansi; Perlu pelatihan yang lebih intensif detkait pengelolaan media sosial milik instansi kesehatan dan pengemasan pesan dengan tujuan promosi kesehatan.
\end{abstract}

Kata Kunci: Promosi Kesehatan, Humas Rumah Sakit, Pengelolaan Media Sosial.

\begin{abstract}
Health workers and health agencies had responsibility to held health promotion activity. However, during the pandemic, many health promotion activities cannot be implemented. On the other hand, there are many hoax news circulating on social media, because people prefer social media and television as a main source of information. For this reason, health promotion are needed through social media. The purpose of this training activity is to increase understanding of health promotion for health workers, increase understanding of health promotion and its relationship with hospital image, and improve the ability to manage messages on social media for health promotion purposes. This activity is a collaboration of the Lecturer Community Service (PPMD) team and the Padjadjaran University Student Real Work Lecture (KKNM) team. This training presents dr. Imran Agus Nurali, Sp.KO., dr. Nurhidayat, M.Kes., DPDK, and Muhammad Afif as speakers. The results of this training activity are, health promoters and target audiences should share the same meaning of health promotion messages; The existence of health promoters in health institutions is important, because it can be a strategy to increase the positive image of the agency; More intensive training is needed regarding the management of social media to health agencies and message packaging with the aim of health promotion.
\end{abstract}

Keyword: Health promotion, hospital public relations, social media management. 


\section{PENDAHULUAN}

Berdasarkan Permenkes No. 44 Tahun 2019 tentang Penyelenggaraan Promosi Kesehatan Rumah Sakit (PKRS), rumah sakit wajib menyelenggarakan PKRS dengan prinsip paradigma sehat, kesetaraan, kemandirian, keterpaduan, dan kesinambungan (Menteri Kesehatan Republik Indonesia, 2018). Namun akibat pandemi, sejak 2020 beberapa fasilitas kesehatan terpaksa mengurangi layanan rawat jalan (Direktur Jenderal Pelayanan Kesehatan, 2020). Hal tersebut membuat kegiatan promosi kesehatan rumah sakit sulit dilakukan. Poster, brosur, banner, leaflet, dan spanduk yang terpasang di area rumah sakit, tidak bisa dibaca oleh warga yang berada dirumah. Beberapa perubahan jadwal konsultasi dengan tenaga ksehatan tidak terinformasikan pada pasien. Kegiatan penyuluhan kesehatan yang biasanya diadakan di area rumah sakit pun tidak bisa dilakukan. Padahal kegiatan penyuluhan menjadi salah satu kegiatan strategis untuk mengkampanyekan paradigma sehat. Perlu adanya strategi baru terkait pelaksanaan promosi kesehatan di masa pandemi.

Jika melihat data pengguna media sosial di Indonesia yang terus meningkat setiap tahunnya, maka media sosial dapat menjadi salah satu media alternatif dalam pelaksanaan promosi kesehatan. Merujuk pada data We Are Social tahun 2020, jumlah pengguna media sosial aktif di Indonesia sebanyak 59\% dari jumlah penduduk Indonesia. Artinya lebih dari 160 juta orang menghabiskan waktu selama 3 jam 26 menit setiap harinya untuk berselancar di media sosial (We Are Social Inc., 2020).

Kehadiran informasi kesehatan di media sosial menjadi amat penting karena berdasarkan survei Katadata Insight Cemter (KIC) bersama Kementerian Komunikasi dan Informatika (Kominfo) pada 1.670 responden, $76 \%$ dari reonden mencari informasi melalui media sosial (Burhan, 2020). Lebih lanjut dalam survei tersebut dikatakan bahwa, jumlah responden yang mempercayai televisi 49,5\% dan media sosial 20,3\%. Jumlah ini lebih besar jika dibandingkan dengan jumlah responden yang mempercayai situs pemerintah sebanyak 15,3\% (Burhan, 2020). Walau responden mengetahui bahwa informasi di situs pemerintah lebih terjamin kebenarannya, mereka lebih memilih media sosial sebagai sumber informasi dengan alasan informasi di media sosial dinilai lebih jelas dan lengkap. Ini dapat menjadi tantangan sekaligus peluang bagi instansi pemerintah khususnya lembaga kesehatan untuk menjadi sumber informasi yang terpercaya bagi masyarakat dengan konten promosi kesehatan yang menarik dan edukatif.

Di media sosial konten promosi kesehatan harus bersaing dengan konten hoks yang banyak ditemukan. Dikatakan bahwa 30-60\% pengguna media sosial di Indonesia terpapar hoaks politik, kesehatan maupun agama. Namun, hanya $21-26 \%$ dari pengguna yang mampu mengenali hoaks (Burhan, 2020).

Peraturan Kementerian Kesehatan no 44 tahun 2018 telah menetapkan standar promosi kesehatan rumah sakit. Bentuk organisasi promosi kesehatan di Rumah Sakit Kelas A dan B minimal adalah berupa instalasi, rumah sakit kelas $C$ dan $D$ minimal berupa unit, dan untuk rumah sakit kelas D Pratama minimal berupa tim (Menteri Kesehatan Republik Indonesia, 2018). Tugas dan fungsi unit promosi kesehatan ini salah satunya adalah membuat dan mengembangkan 
media promosi kesehatan yang tepat, dimana data dan informasi yang disampaikan adalah infotmasi yang valid/akurat.

Dalam hal ini Tenaga Kesehatan di Rumah Sakit khususnya unit promosi kesehatan memiliki peran penting dalam menyampaikan informasi kesehatan kepada masyarakat. Tidak hanya memberikan informasi, tenaga kesehatan juga berperan dalam mempersuasi dan mengedukasi masyarakat mengenai Perilaku Hidup Bersih Sehat (PHBS) khususnya terkait kondisi pandemi saat ini. Informasi penyakit, virus, obat, vaksin, gizi, dan informasi kesehatan lainnya kerap dibutuhkan oleh masyarakat. Melalui komunikasi, informasi tersebut dapat disampaikan dengan berbagai media kepada masyarakat khususnya terkait pencegahan Covid-19 dan vaksin yang saat menjadi perhatian pemerintah.

Unit Promosi Kesehatan Rumah Sakit dapat mensosialisasikan informasi kesehatan dan berbagai kegiatan kesehatan kepada pasien yang menjadi warganet pengikut di akun media sosial rumah sakit. Menurut Laswell (Mulyana, 2000) komunikasi adalah proses penyampaian pesan dari komunikator menggunakan saluran tertentu kepada komunikan, yang menimbulkan dampak atau feedback tertentu. Cara untuk menjelaskan proses komunikasi adalah dengan menjawab pertanyaan siapa, mengatakan apa, melalui media apa, dan kepada siapa? Dengan dampak apa? (Who? Says what? In which channel? To whow? With what effect?). Komunikasi menjadi bagian penting dalam sebuah promosi kesehatan rumah sakit. Dalam hal ini, tenaga kesehatan berperan sebagai komunikator dalam menyampaikan berbagai informasi kesehatan kepada masyarakat.

Kotler dan Keller (Kotler \& Keller, 2009) mengemukakan bahwa promosi adalah sarana informasi perusahaaan, dimana perusahaan berupaya memberikan informasi, membujuk, dan mengingatkan konsumen mengenai produk dan merk yang ditawarkan, baik secara langsung maupun tidak langsung. Selanjutnya, menurut Kotler dan Amstrong (Kotler \& Amstrong, 2012) promosi adalah media komunikasi antara perusahaan dan konsumen dimana perusahaan menginformasikan produk dan jasa yang dihasilkan sebagai upaya membangun hubungan yang saling menguntungkan. Literatur lain menjelaskan bahwa media sosial berkontribusi secara positf pada upaya promosi kesehatan. Untuk itu promotor kesehatan perlu merancang model promosi kesehatan berbasis media sosial dengan mengintegrasikan media sosial dengan strategi promosi kesehatan (Leonita \& Jalinus, 2018). Untuk itu rumah sakit membutuhkan media komunikasi yang tepat untuk menyampaikan informasi kesehatan, menghimbau, serta mengedukasi publik sasaran untuk dapat secara efektif menangkap pesan berisi promosi hidup sehat.

Sebuah penelitian mengenai implementasi PKRS di sebuah rumah sakit swasta di dearah Tangerang menujukan bahwa meskipun telah adanya dukungan dan komitmen namun pelaksana masih belum optimal (Febrian, Permatasari, Nurrizka, \& Hardy, 2020). Hal ini disebabkan kurangnya sumber daya yang dimiliki, komunikasi internal yang belum efektif dan hambatan berupa sikap pihak manajemen terkait konsep promosi kesehatan. Penelitian lain terkait pelaksanaan PKRS dilakukan di RS Universitas Airlangga yang memiliki komitmen mendukung jalannya PKRS. Dengan tim yang berasal dari multi disiplin ilmu, kebijakan manajemen, 
penyediaan anggaran promosi, dan kemitraan dengan Lembaga terkait yang mendukung pelaksanaan promosi kesehatan (Nurdianna, 2017).

Berdasarkan latarbelakang yang telah dipaparkan maka peneliti mengadakan "Pelatihan Promosi Kesehatan pada Tenaga Kesehatan di Jawa Barat." Pelatihan ini dirancang untuk dapat meningkatkan keahlian tenaga kesehatan dalam berkomunikasi melalui media sosial. Peserta juga mendapat informasi bagaimana promosi kesehatan dapat meningkatkan image rumah sakit serta pemahaman media sosial dan teknik praktis pembuatan konten promosi kesehatan di media sosial juga diberikan dalam pelatihan ini. Adapaun tujuan dari kegiatan pelatihan ini adalah meningkatkan pemahaman promosi kesehatan bagi tenaga kesehatan, meningkatkan pemahaman promosi kesehatan serta hubungannya dengan citra rumah sakit, dan meningkatkan kemampuan pengelolaan pesan di media sosial untuk tujuan promosi kesehatan.

\section{METODOLOGI PELAKSANAAN}

Kegiatan pelatihan promosi kesehatan pada tenaga kesehatan di Jawa Barat ini merupakan kegiatan Pengabdian Pada Masyarakat Dosen (PPMD) yang terintegrasi dengan program Kuliah Kerja Nyata Mahasiswa (KKNM) Universitas padjadjaran. Kegiatan PPM ini juga merupakan bagian dari sebuah penelitian yang sedang dilaksanakan dengan tema yang serupa yakni, "Implementasi Promosi Kesehatan Rumah Sakit di Jawa Barat." Dalam pelaksanaannya PPMD ini melibatkan mahasiswa sebagai panitia pelaksana sekaligus fasilitator pelatihan.

Gambar 1. Poster Kegiatan Pelatihan Promosi Kesehatan bagi tenaga Kesehatan di Jawa Barat

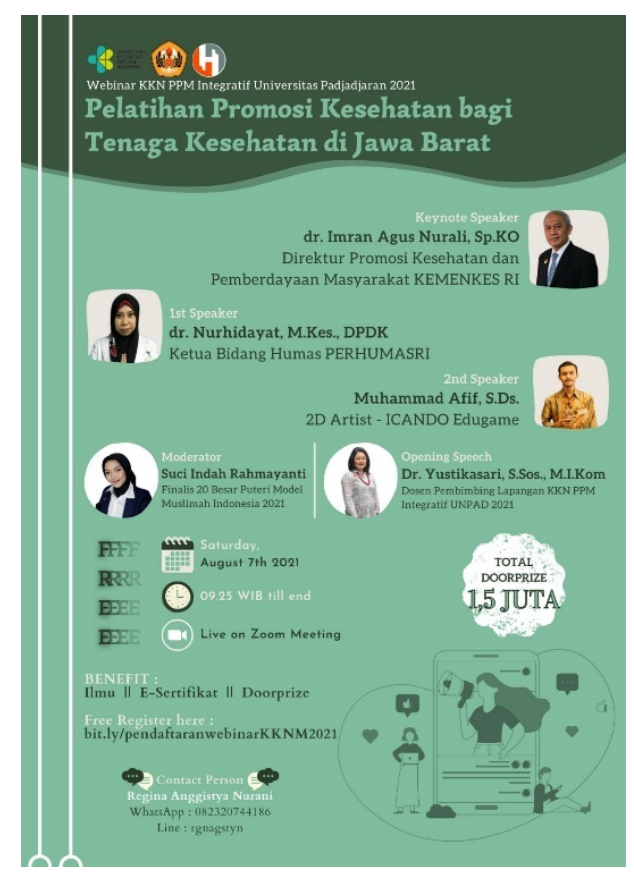

Sumber: Dokumentasi Peneliti 
Pelaksanaan pelatihan ini menggunakan dua teknik yaitu pemberian materi secara langsung (ceramah) melalui media zoom meeting dan diskusi interaktif yang merupakan pemecahan berbagai masalah yang dialami. Dengan pelatihan ini diharapkan peserta dapat mengatasi berbagai masalah yang berkaitan promosi kesehatan khususnya di media sosial yang harus dimiliki peserta dalam menjalankan tugasnya.

Tabel 1. Tahapan Kegiatan Pengabdian Pada Masyarakat

\begin{tabular}{|c|c|c|c|c|}
\hline \multirow{2}{*}{ No } & \multirow{2}{*}{ Kegiatan } & \multicolumn{3}{|c|}{ Keterlibatan dalam kegiatan } \\
\hline & & Dosen & \multirow[b]{2}{*}{\begin{tabular}{|l|}
\multicolumn{2}{|c|}{ Mahasiswa } \\
Mencari \\
narasumber, \\
membuat TOR, \\
dan promosi \\
pada calon \\
peserta \\
pelatihan \\
\end{tabular}} & Peserta \\
\hline 1 & Persiapan & $\begin{array}{l}\text { Mengurus } \\
\text { perizinan, } \\
\text { merumuskan } \\
\text { TOR } \\
\text { narasumber }\end{array}$ & & $\begin{array}{l}\text { Sebagai calon } \\
\text { peserta } \\
\text { kegiatan }\end{array}$ \\
\hline 2 & Survei & Coding data IG & Coding data IG & - \\
\hline \multirow[t]{5}{*}{3} & Pelatihan & & & \\
\hline & $\begin{array}{l}\text { Pemberian Materi Promosi } \\
\text { Kesehatan }\end{array}$ & $\begin{array}{l}\text { Merumuskan } \\
\text { TOR } \\
\text { narasumber }\end{array}$ & $\begin{array}{l}\text { Menjadi } \\
\text { fasilitator }\end{array}$ & $\begin{array}{l}\text { Mengikuti } \\
\text { pelatihan }\end{array}$ \\
\hline & $\begin{array}{l}\text { Pemberian Materi Promosi } \\
\text { Kesehatan dan Branding }\end{array}$ & $\begin{array}{l}\text { Merumuskan } \\
\text { TOR } \\
\text { narasumber }\end{array}$ & $\begin{array}{l}\text { Menjadi } \\
\text { fasilitator }\end{array}$ & $\begin{array}{l}\text { Mengikuti } \\
\text { pelatihan }\end{array}$ \\
\hline & $\begin{array}{l}\text { Praktik pembuatan konten } \\
\text { media sosial }\end{array}$ & $\begin{array}{l}\text { Merumuskan } \\
\text { TOR } \\
\text { narasumber }\end{array}$ & $\begin{array}{l}\text { Menjadi } \\
\text { fasilitator }\end{array}$ & $\begin{array}{l}\text { Mengikuti } \\
\text { pelatihan }\end{array}$ \\
\hline & Diskusi tanya jawab & $\begin{array}{l}\text { Berdiskusi } \\
\text { Bersama } \\
\text { peserta dan } \\
\text { narasumber }\end{array}$ & $\begin{array}{l}\text { Menjadi } \\
\text { fasilitator }\end{array}$ & $\begin{array}{l}\text { Terlibat dalam } \\
\text { diskusi }\end{array}$ \\
\hline 4 & Evaluasi & $\begin{array}{l}\text { Melakukan } \\
\text { evaluasi } \\
\text { kegiatan, } \\
\text { membuat } \\
\text { laporan PPMD }\end{array}$ & $\begin{array}{l}\text { Membuat } \\
\text { laporan } \\
\text { kegiatan KKN }\end{array}$ & - \\
\hline
\end{tabular}

\section{HASIL DAN PEMBAHASAN}

Kami melakukan penelitian awal, dengan melakukan survei pada 13 akun media sosial Rumah 
Sakit milik pemerintah di Jawa Barat. Ada dua akun media sosial yang paling banyak digunakan yakni Facebook dan Instagram, namun peneliti hanya mengkaji Instagram, karena merupakan media sosial yang paling aktif digunakan di sebagian besar rumah sakit yang menjadi sampel. Kami melakukan kategorisasi pada konten yang ditayangkan diantaranya, event, pengumuman, hari peringatan, dan promosi kesehatan, kemudian menghitung semuanya dan persentasenya. Hasil menunjukan terdapat 32\% konten event, konten ini memuat dokumentasi kegiatan, rapat, peresmian gedung, kegiatan memperingati hari besar dan sebagainya. Konten pengumuman sebanyak $28 \%$, berisi informasi perubahan jadwal, pembukaan atau penutupan poliklinik, dan pengumuman pelaksanaan sebuah kegiatan. Untuk Konten hari peringatan terdapat 20\%, berisi peringatan hari besar nasional, hari ulang tahun pemerintah daerah, dan hari peringatan penyakit tertentu. Konten Promosi kesehatan jumlahnya $20 \%$ dari total konten, berisi tentang himbauan cuci tangan, pemakaian masker, pola makan, dan masih banyak lagi.

\section{Gambar. 2 Tema Konten Instagram Rumah Sakit Pemerintah di Jawa Barat}

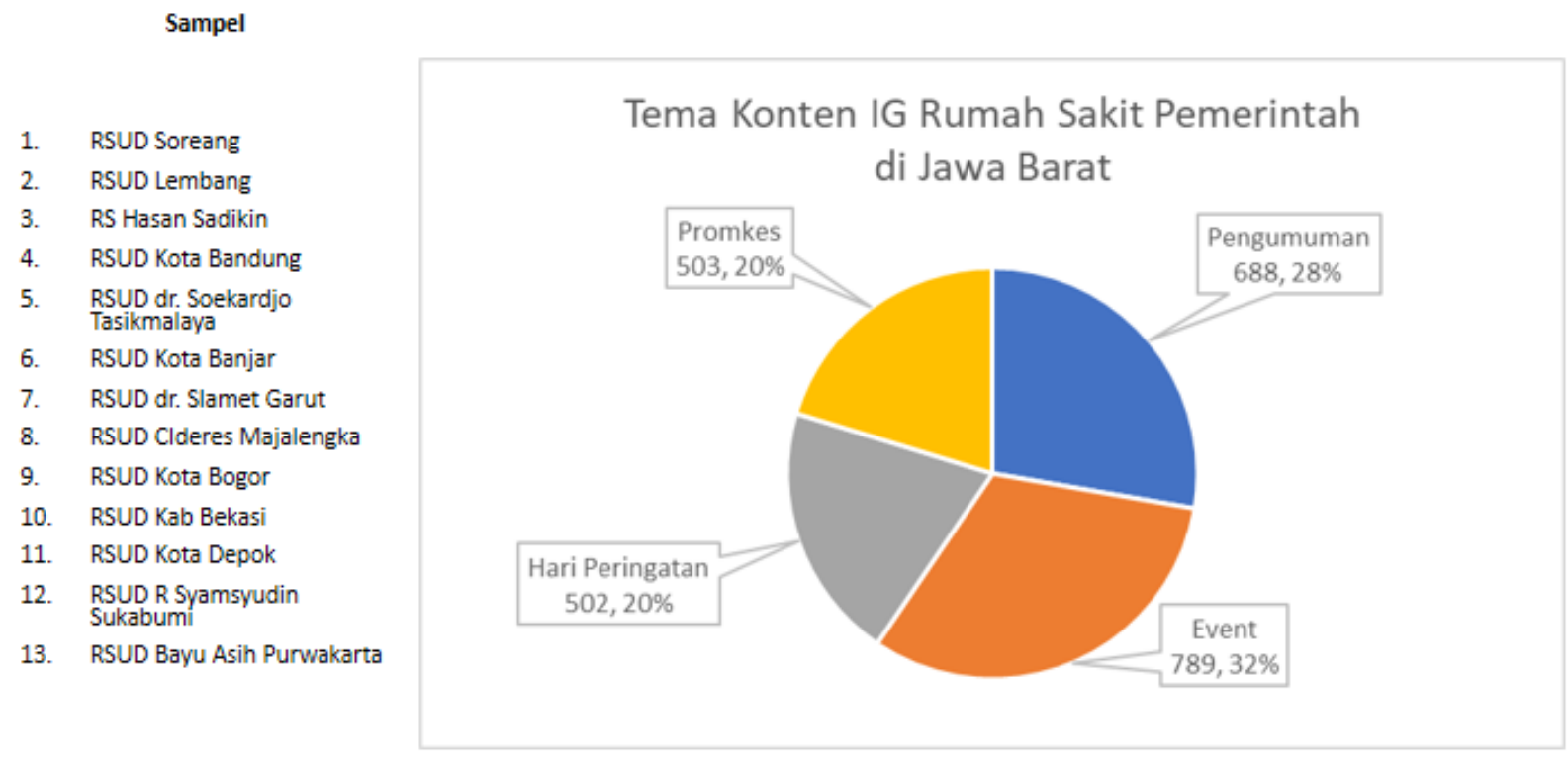

Sumber: Data Penelitian

Data ini menunjukan promosi kesehatan di media sosial millik rumah sakit, masih belum menjadi konten utama. Anggapan bahwa konten hari peringatan penyakit tertentu merupakan promosi kesehatan, rasanya perlu diluruskan. Konten promosi kesehatan yang informatif, berisi pencegahan, perawatan, pengobatan atau fakta yang meluruskan informasi hoaks dari penyakit tertentu bukan hanya peringatan hari penyakit tertentu.

Pelatihan promosi kesehatan bagi tenaga kesehatan ini dilakukan atas dasar penelitian yang bertema "Implementasi Promosi Kesehatan Rumah Sakit di Jawa Barat." Dalam penelitian ini, peneliti menemukan Unit PKRS di rumah sakit pemerintah mengalami kesulitan untuk melaksanakan promosi kesehatan di masa pandemi. Intervensi langsung pada pasien, komunitas 
pasien, dan masyarakat sekitar dibatasi. Kunjungan rumah sakit pun berkurang, dikarenakan banyak rumah sakit pemerintah yang menjadi rujukan covid. Sehingga jumlah pasien umum berkurang cukup banyak.

Kegiatan PPMD-KKNM Intergratif dengan tema "Pelatihan Promosi Kesehatan bagi Tenaga Kesehatan di Jawa Barat" diadakan secara daring pada hari Sabtu, 7 Agustus 2021 pukul 09.25 WIB. Acara yang berlangsung selama dua jam ini, dihadiri oleh 160 peserta, dari latarbelakang tenaga kesehatan, staff promosi kesehatan, humas rumah sakit, staff administrasi rumah sakit/puskesmas dan pelajar/mahasiswa kesehatan. Keynote speaker dalam acara ini, dr. Imran Agus Nurali, Sp.KO, beliau adalah Direktur Promosi Kesehatan dan Pemberdayaan Masyarakat Kementerian Kesehatan Republik Indonesia. Pelatihan ini menghadirkan dua narasumber dari background yang berbeda. Pertama dr. Nurhidayat, M.Kes., DPDK, Ketua Bidang Humas Persatuan Humas rumah Sakit Seluruh Indonesia (PERHUMASRI) dan Muhammad Afif, S.Ds. seorang 2D Artist dari ICANDO Edugame.

Dr. Yustikasari, M.Si sebagai ketua tim peneliti membuka pelatihan dengan memaparkan data hasil coding dari IG 13 rumah sakit pemerintah di Jawa Barat. Acara ini dimoderatori oleh salah satu mahasiswa KKN yaitu Suci Indah Rahmayanti.

\section{Gambar 3. Promosi Kesehatan Rumah Sakit Melalui Media Sosial}

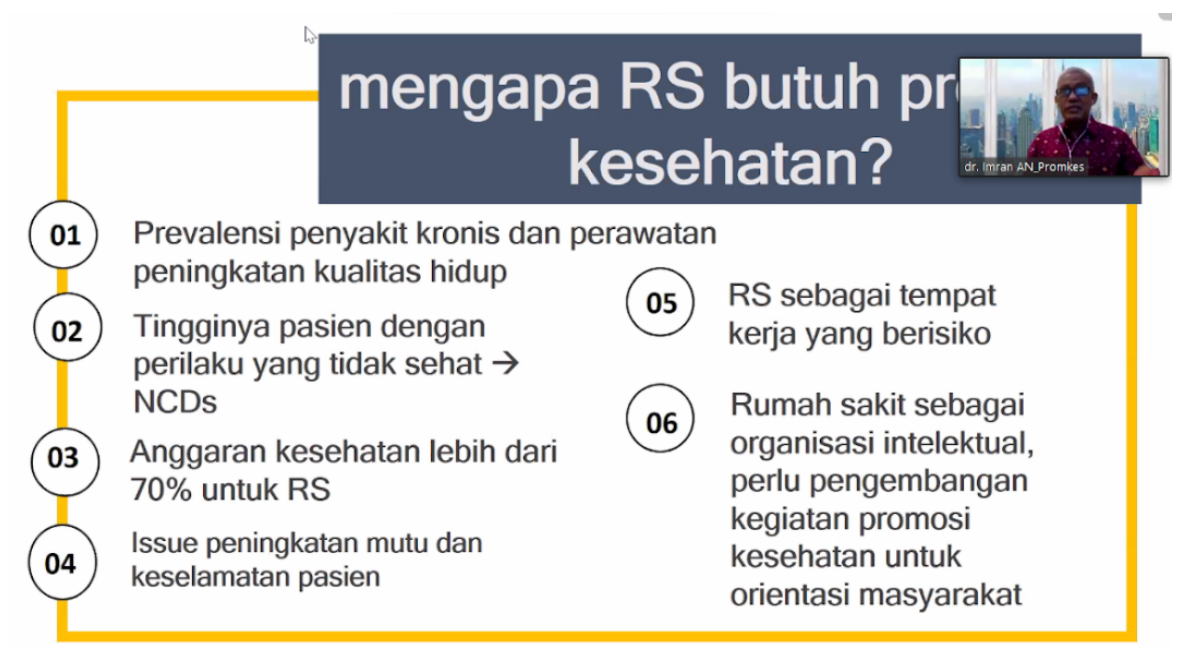

Sumber. (Nurali, 2021)

Dalam paparannya dr. Imran Agus Nurali, Sp.KO menegaskan bahwa Rumah Sakit harus melakukan Promosi Kesehatan. Ada enam alasan mengapa Rumah Sakit membutuhkan Promosi Kesehatan yaitu untuk prevalensi penyakit kronis dan perawatan peningkatan kualitas hidup pasien; kedua masih tingginya pasien yang sakit akibat dari perilaku yang tidak sehat; ketiga anggaran di Kementerian Kesehatan 70\% diperuntukan untuk Rumah Sakit; keempat, issue peningkatan mutu dan keselamatan pasien perlu diutamakan; kelima, Rumah sakit adalah tempat kerja yang paling berisiko dalam penularan penyakit; dan terakhir Rumah sakit sebagai 
organisasi intelektual, perlu pengembangan kegiatan promosi kesejatan yang berorientasi masyarakat (Nurali, 2021). Karena saat ini masih terdapat unit promosi kesehatan yang dibentuk hanya untuk kepentingan akreditasi semata, jadi pengelolaan pesan promosi kesehatannya tidak maksimal.

Gambar 4. Promosi Kesehatan dalam meningkatkan Citra dan Branding Rumah Sakit

\author{
Peran strategis media \\ 1. MEMBANGUN REPUTASI INSTITUSI \\ 2. MENGUBAH POLA PIKIR DAN PERILAKU \\ MASYARAKAT \\ 3. PEMBERDAYAAN MASYARAKAT
}

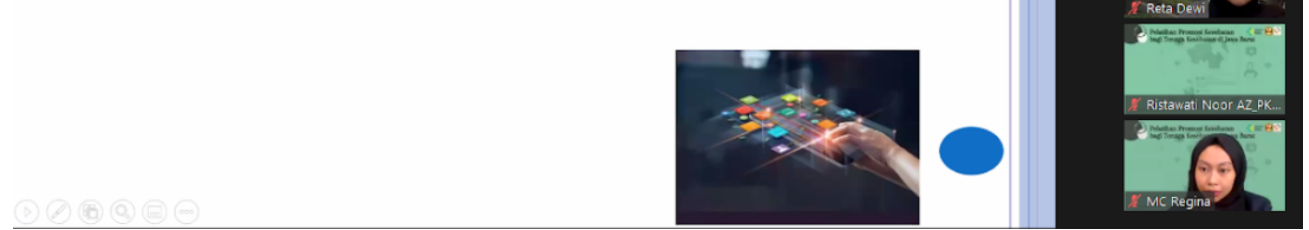

Sumber (Nurhidayat, 2021)

Narasumber pertama dalam pelatihan ini adalah dr. Nurhidayat, M.Kes., DPDK, beliau mewakili Persatuan Humas Rumah Sakit Seluruh Indonesia, memaparkan topik bagaimana peran Promosi Kesehatan dalam membangun citra positif rumah sakit (Nurhidayat, 2021). Dalam paparannya beliau menyampaikan bahwa media komunikasi memiliki peran strategis dalam melakukan pemberdayaan masyarakat. Sehingga media sosial yang dimiliki rumah sakit, tidak hanyak diperuntukan dalam membangun citra dan pemasaran tapi juga untuk promosi kesehatan. Marketing, humas dan promosi kesehatan harus berjalan seiringan, dan setiap orang dalam instansi harus didorong untuk menjadi humas yang menyebarkan pesan positif dari rumah sakit.

Gambar 5. Handal dalam Komunikasi Digital

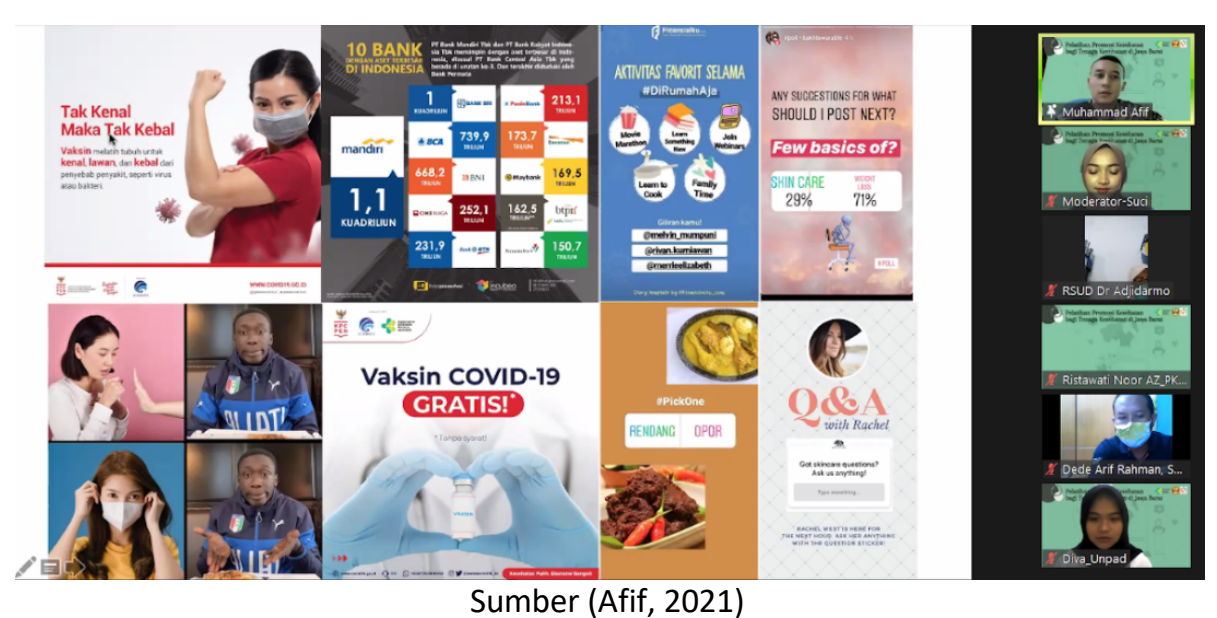


Narasumber kedua dalam pelatihan ini menyampaikan materi bagaimana agar tenaga kesehatan handal dalam komunikasi digital. Muhammad Afif, S.Ds. mengemukakan bahwa beberapa media sosial rumah sakit menampilakan konten yang tidak ramah untuk pengguna sosial media, seperti menampikan poster yang terlalu kecil dengan informasi yang teramat padat. Melihat kebutuhan audience sasaran di media sosial, ada baiknya media sosial rumah sakit menampilakn konten yang tidak terlalu kaku dan mengikuti trend yang berkembang, namun tetap berhubungan dengan citra yang ingin ditampilkan rumah sakit (Afif, 2021). Hal ini agar media sosial rumah sakit dapat lebih banyak menjangkau audience. Dengan lebih banyak audience yang dijangkau maka akan lebih banyak masyarakat yang terinformasi pesan promosi kesehatan.

Setelah semua paparan dari narasumber, acara berlanjut ke sesi diskusi dan tanya jawab. Peserta pelatihan sangat antusias sekali mengikuti rangkaian kegiatan dari awal sampai akhir acara. Terdapat lima orang penanya yang terpilih untuk mewakili peserta lain. Pertanyaan seputar media sosial dijawab oleh Muhammad Afif dan pertanyaan seputar promosi kesehatan, humas dan aplikasinya dalam tugas di Rumah Sakit ditanyakan pada dr. Nurhidayat.

Dengan adanya pelatihan ini diharapkan dapat memberi manfaat secara langsung dapat di terapkan oleh tenaga kesehatan khususnya unit Promosi Kesehatan dalam menngemas pesan promosi kesehatan di media sosial. Dengan promosi kesehatan yang efektif, diharapkan media sosial rumah sakit dapat menjadi salah satu sumber informasi kesehatan terpercaya bagi masyarakat dan berdampak pada citra positif dari rumah sakit.

\section{SIMPULAN}

Program Pengabdian Pada Masyarakat Dosen (PPMD) dan Kuliah Kerja Nyata Mahasiswa (KKNM) yang bertema Pelatihan Promosi Kesehatan pada Tenaga Kesehatan di Jawa Barat telah terselenggara dengan baik secara daring pada hari Sabtu, 7 Agustus 2021. Peserta yang hadir di ruang zoom meeting mencapai 160 orang. Terdiri dari berbagai latar belakang seperti mahasiswa jurusan kesehatan, promotor kesehatan, penyuluh kesehatan masyarakat, tenaga kesehatan, dosen/guru, ASN dan pelajar.

Berdasarkan kegiatan pelatihan yang telah dilaksanakan, dapat disimpulkan bahwa pemahaman mengenai pesan promosi kesehatan perlu disamakan antara promotor kesehatan dan audience sasaran. Keberadaan promotor kesehatan di instansi kesehatan menjadi amat penting, karena dapat menjadi strategi peningkatan citra positif instansi. Perlu pelatihan yang lebih intensif terkait pengelolaan media sosial milik instansi kesehatan dan pengemasan pesan dengan tujuan promosi kesehatan.

Saran kami untuk tindak lanjut dari penyuluhan ini adalah dibutuhkan adanya riset lebih lanjut terkait pesan promosi kesehatan. Agar pesan promosi kesehatan dapat sampai tepat sasaran, maka perlu adanya kesamaan persepsi terkait seperti apa pesan bentuk promosi kesehatan antara audience sasaran dan promotor kesehatan. Untuk meningkatkan penelolaan media sosial 
milik instansi kesehatan, diperlukan adanya workshop khusus yang membimbing secara intensif para promotor kesehatan, khususnya yang memiliki tugas mengelola media sosial.

\section{UCAPAN TERIMA KASIH}

Kegiatan pelatihan peromosi kesehatan ini merupakan bagian dari program PPMD-KKNM Integratif yang diinisiasi oleh Universitas Padjadjaran. Kegiatan ini terselenggara berkat kerjasama antara dosen, mahasiswa dan masyarakat khususnya para peserta pelatihan. Untuk itu kami ucapkan terima kasih dan apresiasi pada narasumber kami dr. Imran Agus Nurali, Sp.KO., beserta Staf Promosi Kesehatan Kemenkes RI, dr. Nurhidayat, M.Kes., DPDK, beserta tim PERHUMASRI, dan Muhammad Afif. Kami juga mengucapkan terima kasih kepada para peserta yang datang dari berbagai latarbelakang dan daerah di Indonesia. Apresiasi juga kami berikan kepada 10 orang mahasiswa yang bersama-sama mensukseskan kegiatan pelatihan ini, khususnya mba Gilang Mila Permata Indah (Fapet) yang mengetuai teman-teman mahasiswa, kepada Sri Mayang Rahayu (FKep); Dewina Alviani (FISIP), Japar Abdul Aziz (FMIPA), Amanta Akhila (FK), Sulthan Ariq S. Aden (Fikom), Nadya Salsabila S. (FH), Regina Anggistya Nurani (Fisip), Asep Saefurahman (Fikom), dan Suci Indah (FEB). 


\section{DAFTAR PUSTAKA}

Afif, M. (2021, Agustus 7). Handal dalam Komunikasi Digital. Pelatihan Promosi Kesehatan pada tenaga Kesehatan di Jawa barat. Bandung, Jawa barat, Indonesia: Universitas Padjadjaran.

Burhan, F. A. (2020, November 20). Home: Digital: Teknologi. Retrieved from Katadata.co.id: https://katadata.co.id/desysetyowati/digital/5fb7b04fa5eb9/survei-kic-masyarakatlebih-percaya-medsos-ketimbang-situs-pemerintah

Direktur Jenderal Pelayanan Kesehatan. (2020). YR.03.03/III/III8/2020. Kementerian Kesehatan Republik Indonesia.

Febrian, M. R., Permatasari, P., Nurrizka, R. H., \& Hardy, F. R. (2020). Analisis Implementasi Penyelenggaraan Promosi Kesehatan Rumah Sakit di Era Jaminan Kesehatan Nasional. Jurnal Ilmiah Kesehatan Nasional, 12(1).

Kemenkes RI. (2020). Peraturan Menteri Kesehatan Republik Indonesia Nomor 9 Tahun 2020 Tentang Pedoman Pembatasan Sosial Berskala Besar Dalam Rangka Percepatan Penanganan Corona Virus Disease 2019 (Covid-19). . Kementerian Kesehatan Republik Indonesia.

Kementerian KesehatanRepublik Indonesia. (2020). Peraturan Menteri Kesehatan No 20 tahun 2019. Penyelenggaraan Telemedicine antar Fasilitas Pelayanan Kesehatan.

Kotler, P., \& Amstrong, G. (2012). Prinsip-prinsip Pemasaran. Jakarta: Erlangga.

Kotler, P., \& Keller, K. L. (2009). Manajemen Pemasaran. Jakarta: Erlangga.

Leonita, E., \& Jalinus, N. (2018). Peran Media Sosial dalam Upaya Promosi Kesehatan: Tinjauan Literatur. Jurnal Inovasi Vokasi dan teknologi, 18(2), 25-34.

Menteri Kesehatan Republik Indonesia. (2018). Peraturan Menteri Kesehatan Republik Indonesia No. 44 Tahun 2018 tentang Penyelenggaraan Promosi Kesehatan Rumah Sakit. Jakarta, Indonesia: Kementerian Kesehatan republik Indonesia.

Mulyana, D. (2000). Pengantar Ilmu Komunikasi. Bandung: Remaja Rosdakarya.

Nurali, I. A. (2021, Agustus 7). Promosi Kesehatan Rumah Sakit Melalui Media Sosial. Pelatihan Promosi Kesehatan pada Tenaga Kesehatan di Jawa Barat. Bandung, Jawa Barat, Indonesia: Universitas Padjadjaran.

Nurdianna, F. (2017). Pelaksanaan Promosi Kesehatan di Rumah Sakit Universitas Airlangga Surabaya. Promkes, 5(2), 217-231.

Nurhidayat. (2021, Agustus 7). Promosi Kesehatan dalam meningkatkan Citra dan Branding Rumah Sakit. Pelatihan Promosi Kesehatan pada Tenaga Kesehatan di Jawa Barat. Bandung, Jawa Barat, Indonesia: Universitas Padjadjaran.

We Are Social Inc. (2020). Digital 2020. New York: We are Social Inc. . 